\title{
SISTEM INFORMASI ADMINISTRASI DATA KEMAHASISWAAN BERBASIS WEB PADA UNIVERSITAS LANCANG KUNING
}

\author{
Susi Handayani ${ }^{1)}$ \\ ${ }^{1}$ Fakultas Ilmu Komputer, Universitas Lancang Kuning, Jl. Yos Sudarso KM.8, Umban Sari, Rumbai \\ Kota Pekanbaru 28662 \\ email: susi@unilak.ac.id
}

\begin{abstract}
Dari penelitian yang telah dilakukan pada Universitas Lancang Kuning Pekanbaru, khususnya pada Sistem Informasi Administrasi Akademik dikemukakan beberapa hal pokok yang perlu dibahas dan jadi perhatian utama pihak pengolahan data. Hal yang terpenting bahwa pada dasarnya pengolahan data sudah menggunakan sistim basis data secara pinsip, hanya saja belum dioperasikan secara totalitas dalam kinerja elektronis untuk menghasilkan layanan terhadap informasi. Melalui observasi langsung ke lapangan ditemui kelemahan-kelemahan sistem yang ada. Walaupun tidak secara keseluruhan dan lebih mengarah pada masalah yang spesifik, namun diharapkan dapat memberikan kontribusi yang berarti kepada pengguna sistem. Dengan memanfaatkan literatur-literatur ilmu informatika komputer, dan situs-situs yang relevan dengan permasalahan. Diakhiri dengan penelitian laboratorium dengan menerapkan siklus hidup pengembangan perangkat lunak dibuatlah sebuah aplikasi yang diharapkan dapat memecahkan permasalahan yang ada. Dengan menggunakan sistem informasi yang telah teruji kehandalannya, dibantu dengan sistem pelaporan dengan platform yang sudah sangat dikenal dan dengan menggunakan bahasa pemrograman yang berbasis Grafic User Interface serta pemanfaatan penggunaaan jaringan komputer berbasis web yang diharapkan dapat meningkatkan efisiensi kerja bagian yang terkait, hingga pada akhirnya tujuan yang diharapkan dapat tercapai.Dan terutama sekali sasaran akhirnya adalah sebagai sumbangan nyata terhadap ilmu pengetahuan hingga pada gilirannya dapat disajikan informasi yang benar-benar berkualitas.
\end{abstract}

\section{Keywords: Sistem Informasi Akademik, Sistem Informasi Berbasis Web, Graphical User Interface (GUI)}

\section{PENDAHULUAN}

Perguruan Tinggi sebagai pusat intelektual, tempat pengkajian, pemanfaatan penyebaran ilmu pengetahuan dan teknologi, merupakan salah satu komponen dalam upaya mengembangkan ilmu pengetahuan dan teknologi. Kampus adalah sarana yang tepat untuk meningkatkan peran serta dalam penyebaran ilmu pengetahuan dan teknologi. Universitas Lancang Kuning adalah salah satu Perguruan Tinggi Swasta yang berlokasi di Provinsi Riau. Universitas Lancang Kuning memiliki 8 (delapan) fakultas, yaitu Fakultas Ilmu Administrasi, Fakultas Hukum, Fakultas Ekonomi, Fakultas Teknik, Fakultas Ilmu Budaya, Fakultas Pertanian, Fakultas Kehutanan dan yang baru berdiri adalah Fakultas Ilmu Komputer. Selain itu Universitas Lancang Kuning memiliki 2 Biro, yaitu Biro Umum dan Biro Akademis dan
Kemahasiswaan. Biro Umum membawahi Bagian Umum \& Personalia dan Bagian Keuangan, sementara Biro Akademis dan Kemahasiswaan membawahi Bagian Akademis dan Bagian Kemahasiswaan.

Dalam pendataan registrasi mahasiswa, baik itu mahasiswa baru maupun mahasiswa lama, Universitas Lancang Kuning masih didominasi oleh sistem manual yang dilanjutkan dengan penggunaan aplikasi MSOffice (MS-Word dan MS-Excel) apabila data-data tersebut harus dilaporkan ke pihak manajemen.

Dengan prosedur registrasi seperti ini, akan terasa sulit karena perlu dilakukan cross check untuk menjamin konsistensi data antara pihak universitas dengan fakultas. Setiap kali salah satu pihak baik itu pihak universitas maupun fakultas memerlukan data, maka mereka harus melakukan permintaan (request) ke bagian yang bersangkutan sebagai 
penyedia data. Hal ini cukup menyita waktu mengingat jarak antara universitas dengan fakultas-fakultas yang ada cukup jauh (minimal 100 meter).

Oleh sebab itu dibutuhkan penelitian yang terfokus terhadap permasalahan yang ada pada Sistem Informasi Administrasi Data Kemahasiswaaan di Universitas Lancang Kuning Pekanbaru agar solusi yang diberikan dapat menyelesaikan permasalahan secara tuntas.

Rekayasa Ulang Bisnis Proses merupakan sebuah solusi bagi peningkatan Sistem Informasi Administrasi Data Kemahasiswaan di Universitas Lancang Kuning untuk mewujudkan sistem pengelolaan data mahasiswa yang efektif dan efisien.

\section{METODE PENELITIAN}

Kerangka kerja dalam melakukan penelitian ini adalah sebagai berkut:

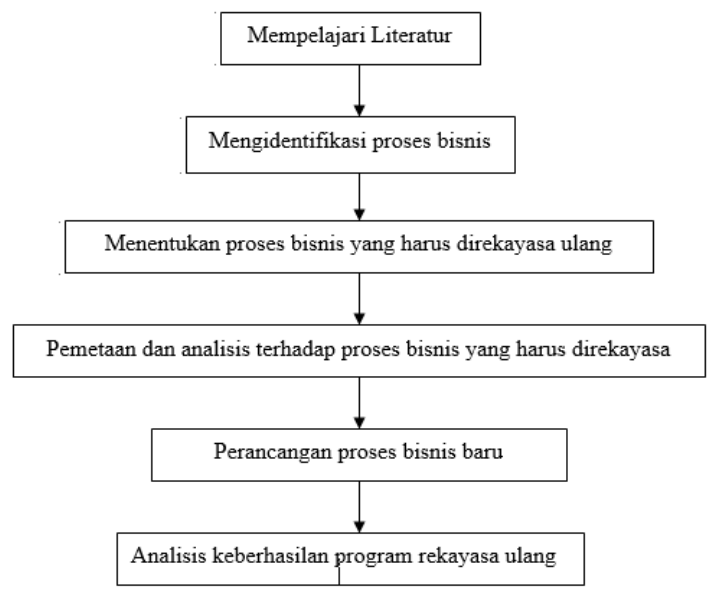

Gambar 2.1 kerangka Kerja Penelitian

\subsection{Aliran Sistem Informasi Yang Sedang Berjalan}

Selengkapnya bentuk aliran data yang dimaksud, dapat dilihat pada bagan aliran sistem informasi pada Gambar 2.2 berikut:

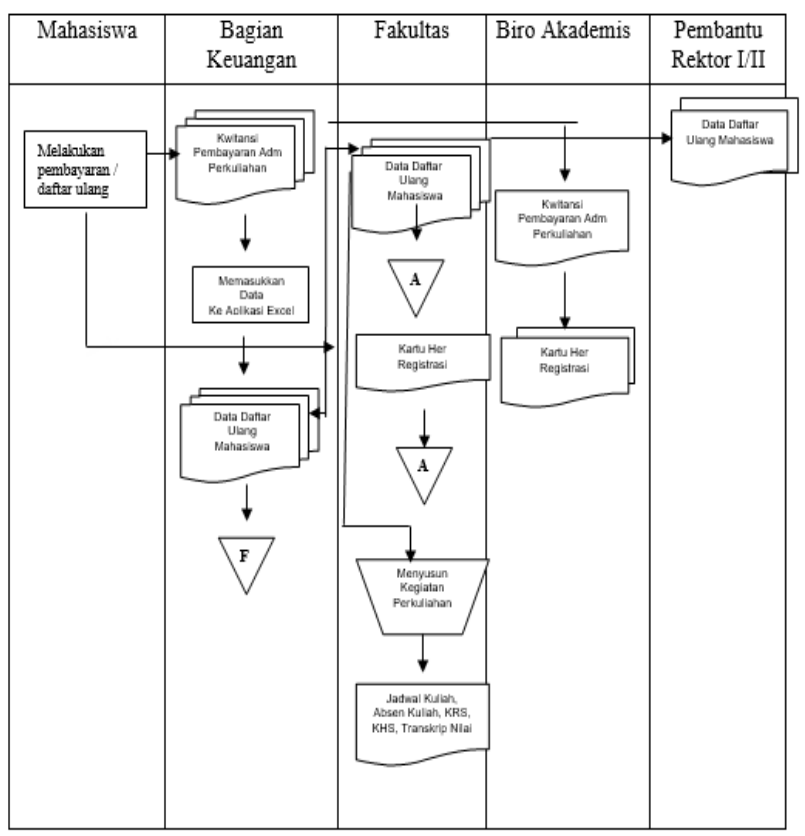

Gambar 2.2 Aliran Sistem Informasi yang sedang Berjalan

Pada bagan di atas terlihat adanya 6 (enam) entiti yang terlibat langsung dengan sistem ini yaitu Mahasiswa, Bagian Keuangan, Biro Akademis, Fakultas, Pembantu Rektor I dan Pembantu Rektor II.

Kuitansi bukti pembayaran administrasi perkuliahan dikoleksi oleh bagian keuangan. Bagian keuangan menyusun data-data sebut ke dalam tabel-tabel dengan menggunakan MS-Excel. Data-data tersebut kemudian diprint dan menghasilkan 3 (tiga) lembaran dokumen. Salah satu lembaran dijadikan sebagai arsip bagian ini. Sementara lembaran yang lainnya diserahkan kepada fakultas sebagai kelengkapan mencetak KHS, jadwal perkuliahan, kartu rencana studi mahasiswa dan transkrip nilai. Di pihak lain, data-data yang ada pada biro akademis berupa kartu registrasi ulang juga diserahkannya ke fakultas untuk selanjutnya diarsipkan oleh bagian ini. Kembali ke fakultas, berkasberkas yang dimilikinya selanjutnya diserahkan kepada Pembantu Rektor I.

\subsection{Aliran Rancangan Sistem Informasi} Administrasi Data Kemahasiswaan

Adapun bentuk rancangan aliran data Sistem Informasi Administrasi dapat dilihat pada bagan aliran sistem informasi pada Gambar 2.3 berikut ini: 


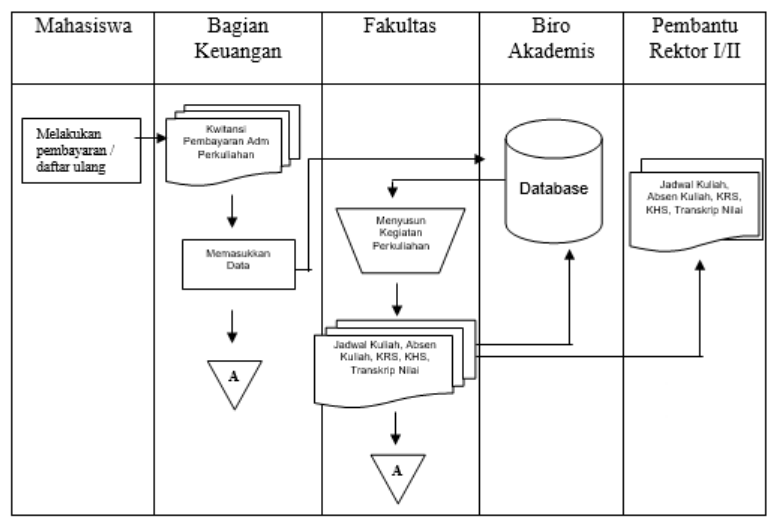

Gambar 2.3 Aliran Perancangan Sistem Informasi

\subsection{Desain Entity Relationship Diagram (ERD) Database}

Diagram hubungan entitas hanya berfokus pada data dengan menunjukkan jaringan data yang ada untuk suatu sistem yang diberikan. Untuk pemodelan data pada Sistem Informasi Administrasi Data Kemahasiswaan Universitas Lancang Kuning ini penulis juga menggunakan diagram hubungan entitas dan desain tabel.

Adapun diagram hubungan entitas pada sistem ini dapat dilihat pada gambar 2.4 berikut ini :

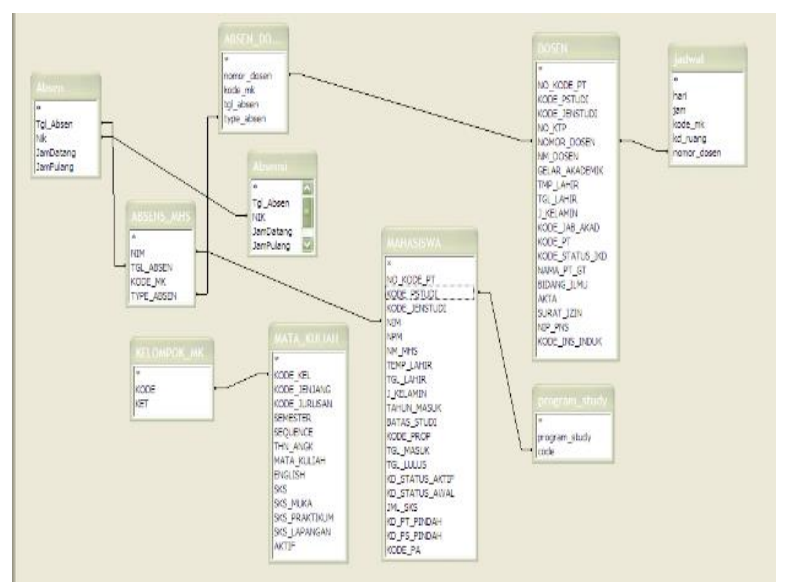

Gambar 2.4 Desain Entity Relationship Diagram (ERD) Database

\subsection{Context Diagram (Diagram}

Konteks) Adapun Diagram Konteks Sistem Informasi Akademis berbasiskan WEB terdapat pada gambar 2.5 berikut ini:

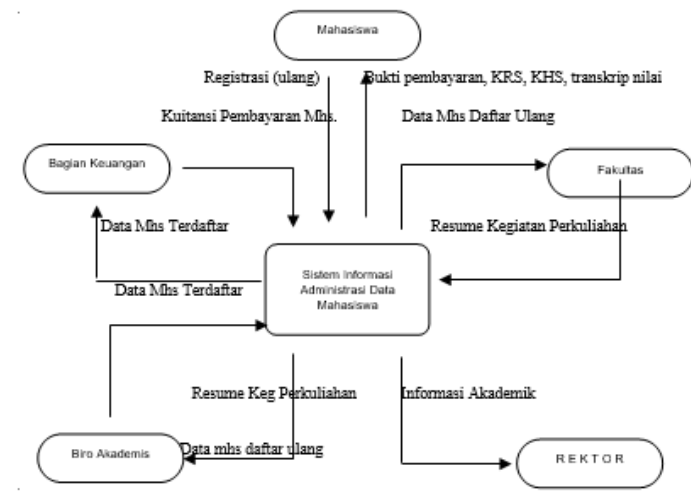

Gambar 2.5 Konteks Diagram Sistem Informasi Administrasi Data Kemahasis waan

\subsection{Rancangan Modul}

Rancangan modul merupakan penjelasan dari setiap proses yang terjadi pada setiap bagian.

1. Registrasi Ulang.

Pada saat registrasi ulang mahasiswa melakukan pembayaran di Bagian Keuangan, dan mengisi biodata lengkap mahasiswa. Bagian Keuangan menginput data mahasiswa ke dalam database untuk kemudian mengirimkan ke server.

2. Pengecekan Status Mahasiswa.

Untuk mahasiswa lama Bagian Keuangan melakukan pengecekan status mahasiswa apakah mahasiswa yang bersangkutan masih aktif kuliah dan untuk konfirmasi apakah pembayaran yang dilakukan telah sesuai.

3. Pengisian Blangko Kartu Rencana Studi (KRS)

Mahasiswa mengisi blangko Kartu Rencana Studi (KRS) untuk kemudian diserahkan ke Biro Akademis.

4. Penerbitan KRS.

Biro Akademis menerbitkan KRS (Kartu Rencana Studi) yang menjadi pedoman bagi mahasiswa dalam mengikuti kegiatan perkuliahan.

\section{Pengentryan KRS}

Biro Akademis mengentry data KRS mahasiswa ke dalam database untuk kemudian dishare kepada fakultas masingmasing.

6. Pembuatan absensi

Biro Akademis menerbitkan absensi kuliah yang menjadi pedoman bagi Fakultas dan Dosen dalam kegiatan perkuliahan.

7. Pengentryan Kartu Hasil Studi (KHS)

Data nilai mahasiswa dimasukkan dalam database dan kemudian Biro Akademis menerbitkan Kartu Hasil Studi (KHS) mahasiswa. 
8. Laporan Informasi Data Kemahasiswaan

Resume Data Kemahasiswaan ini kemudian dilaporkan kepada pimpina tertinggi yaitu Rektor Universitas Lancang Kuning Pekanbaru untuk menjadi bahan evaluasi.

\section{HASIL DAN PEMBAHASAN}

\subsection{Antar Muka (User Interface Design)}

Dalam perancangan Sistem Informasi Administrasi Data Kemahasiswaan ini digunakan 2 aplikasi, yaitu aplikasi yang berbasis Desktop dan aplikasi berbasis Web. Aplikasi berbasis Desktop dikhususkan untuk pengolahan data sementara aplikasi berbasis Web untuk penyedia informasinya.

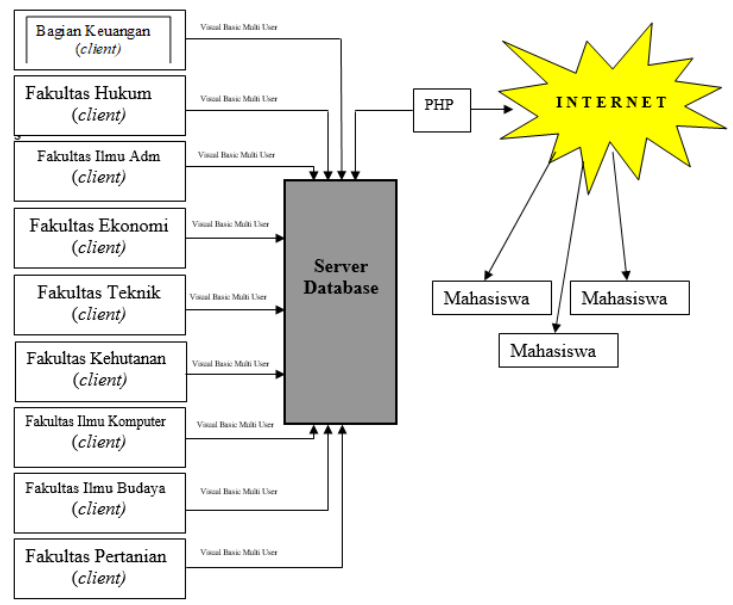

Gambar 3.1 Perancangan Antar Muka (User Interface Design)

\subsection{Desain Aplikasi Berbasis Desktop}

Rancangan yang dikhususkan untuk pengolahan data ini menggunakan bahasa pemrograman Visual Basic 6.0. Setiap bagian (client) diberi akses ke server database untuk pengisian database mahasiswa dan dosen. Dalam hal ini yang bertindak sebagai server adalah Biro Akademis sedangkan client disini yaitu Biro Keuangan dan 8 Fakultas yang ada di lingkungan Universitas Lancang Kuning.

\subsubsection{Format Menu}

Format menu ini adalah tampilan menu-menu yang tersedia, terdiri dari format menu utama, sub menu master tabel akademik, akademik, laporan, laporan ke Dikti, dan Download Excel.

1. Menu Utama:

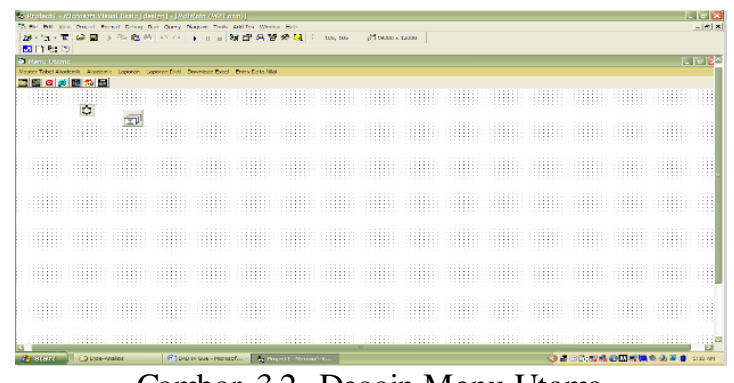

Gambar 3.2. Desain Menu Utama

2. Sub Menu Master Tabel Akademis

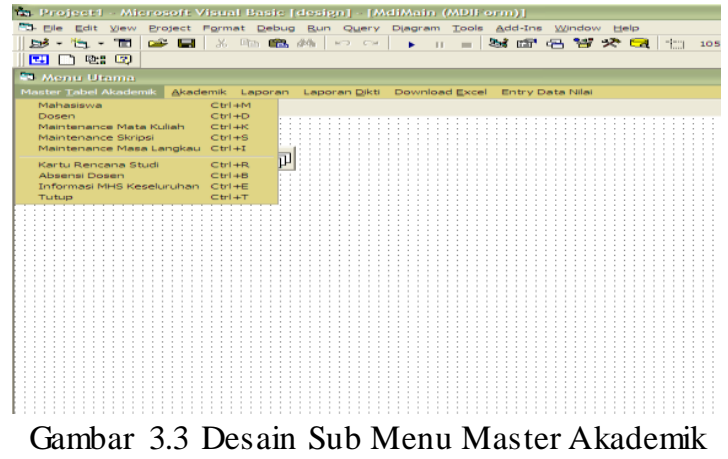

3. Sub Menu Akademik

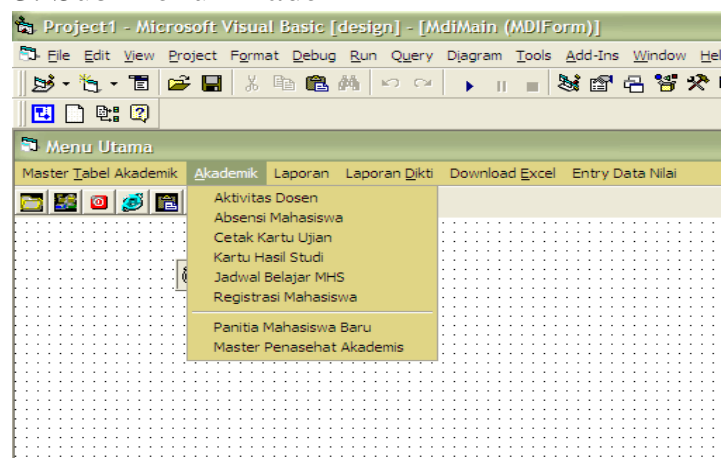

Gambar 3.4 Desain Sub Menu Akademik

4. Sub Menu Laporan

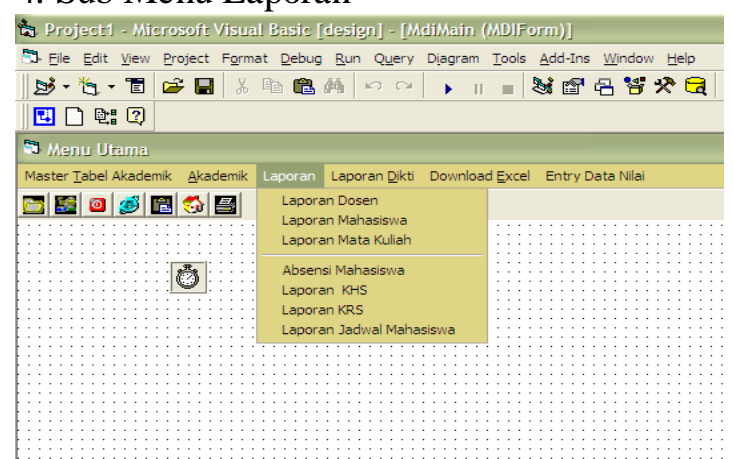

Gambar 3.5 Desain Sub Menu Laporan 
5. Sub Menu Laporan ke Dikti

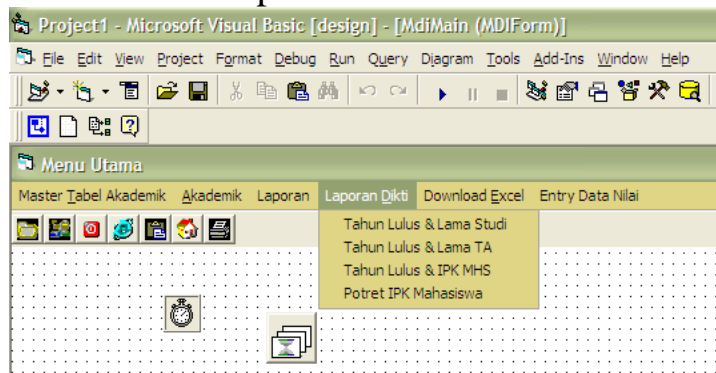

Gambar 3.6 Desain Sub Menu Laporan ke Dikti

6. Sub Menu Download Excel

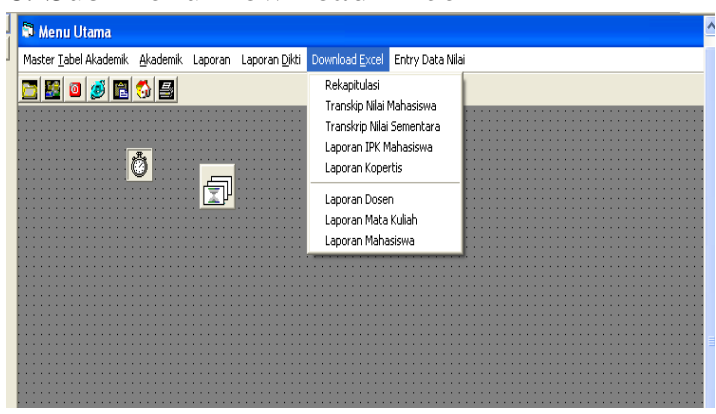

Gambar 3.7 Desain Sub Menu Download Excel

\subsubsection{Rancangan Input}

Rancangan input ini adalah berupa form yang berisi data entity yang nantinya akan disimpan ke dalam file database mahasiswa, mata kuliah, dosen, dan absensi.

1. Desain Form Isian Data Mahasiswa

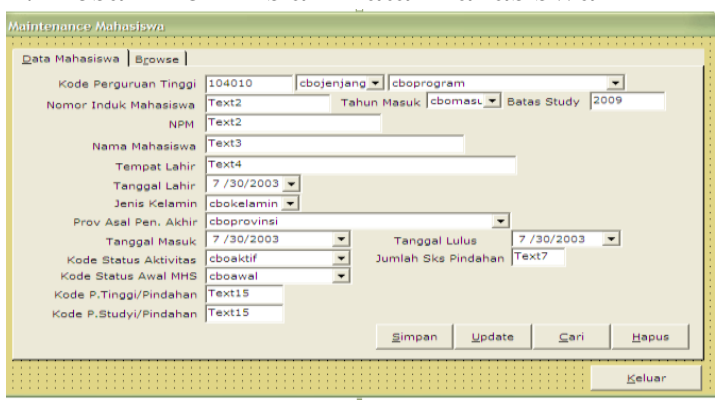

Gambar 3.8 Desain Form Isian Data Mahasiswa

\section{Form Isian Data Mata Kuliah}

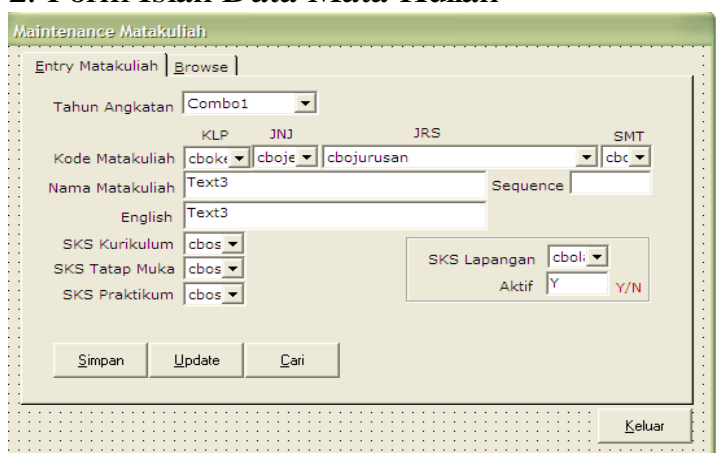

Gambar 3.9 Desain Form Isian Data Mata Kuliah

\section{Desain Form Isian Data Dosen}

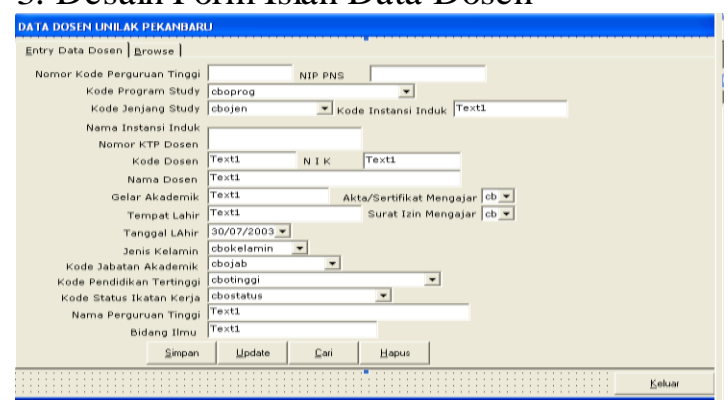

Gambar 3.10 Desain Form Isian Data Dosen

4. Desain Form Isian Data Absensi Mahasiswa

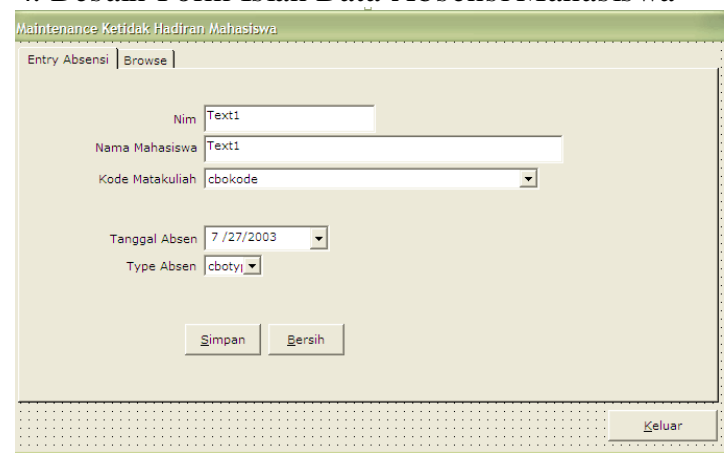

Gambar 3.11 Desain Form Isian Data Absensi Mahasiswa

\section{Desain Form Kehadiran Dosen}

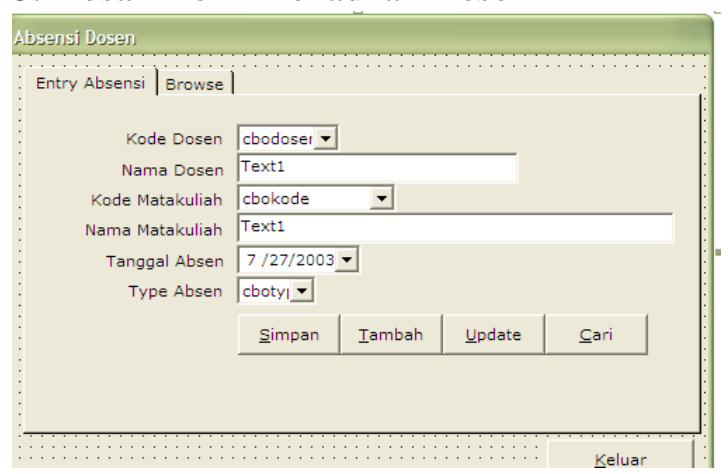

Gambar 3.12 Desain Form Kehadiran Dosen

\section{Desain Form Masa Langkau}

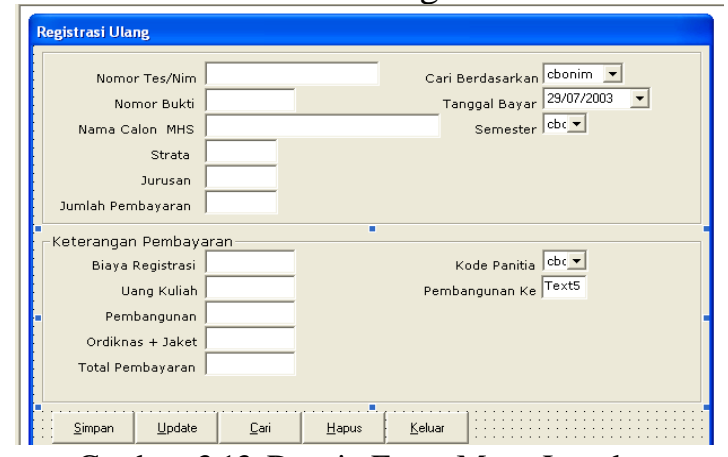

Gambar 3.13 Desain Form Masa Langkau 


\subsection{Desain Aplikasi Berbasis Web}

Berikut ada tampilan Home Page dari aplikasi web :

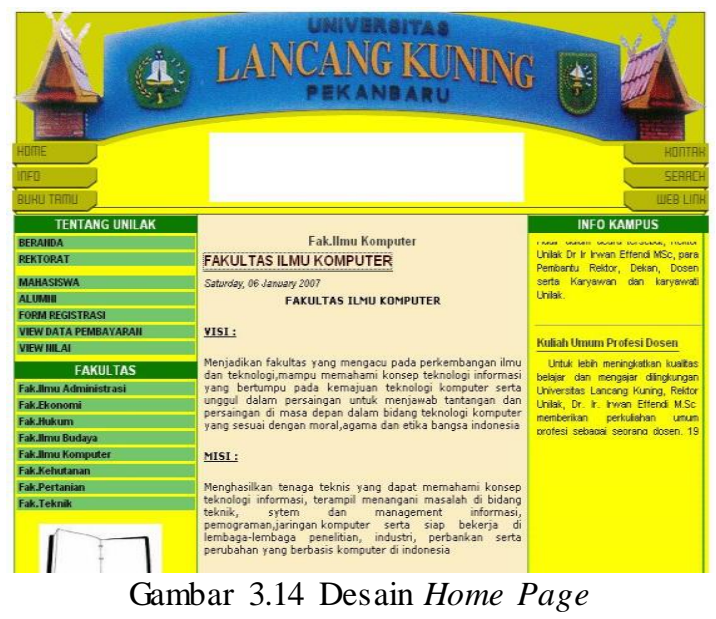

Apabila memilih menu "form registrasi" maka tampilan yang akan muncul di layar adalah sebagai berikut :

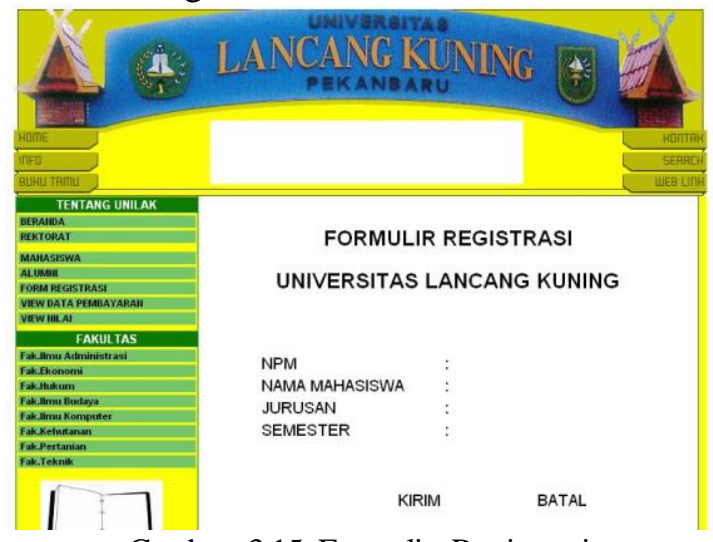

Gambar 3.15 Formulir Registrasi

Formulir registrasi ini digunakan pada saat mahasiswa akan mendaftar secara online dari jarak jauh dan akan diberikan formulir lengkap apabila ia mendatangi kampus pusat Universitas Lancang Kuning Pekanbaru.

Selanjutnya mahasiswa dapat melihat data pembayaran dengan klik "view data pembayaran". Dan tampilan form yang akan muncul adalah sebagai berilkut :

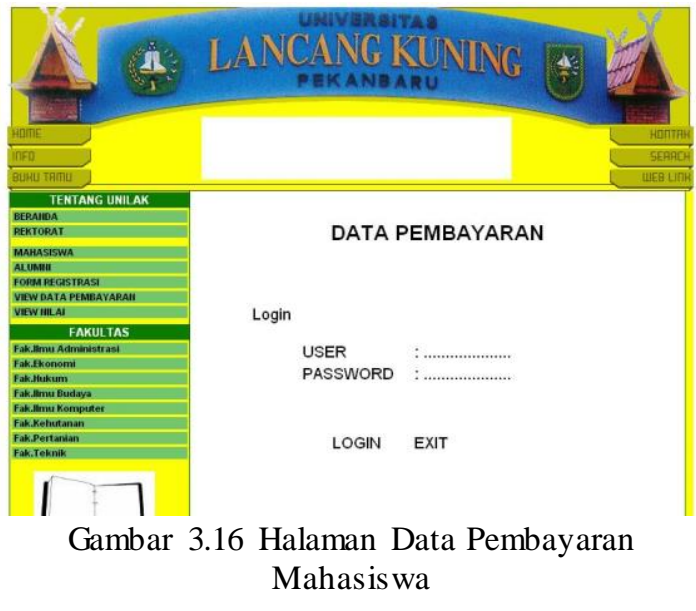

Halaman data pembayaran ini merupakan privasi mahasiswa, dimana untuk masuk ke dalamnya dengan menggunakan user id dan password. Di sini mahasiswa dapat mengakses data pembayarannya karena mahasiswa kelas jauh seringkali tidak secara langsung melunasi pembayaran melainkan melalui pengelola (kolektif).

Selain data pembayaran, mahasiswa juga dapat melihat nilai dengan memilih menu "View Nilai". Tampilan yang akan muncul akan seperti berikut ini :

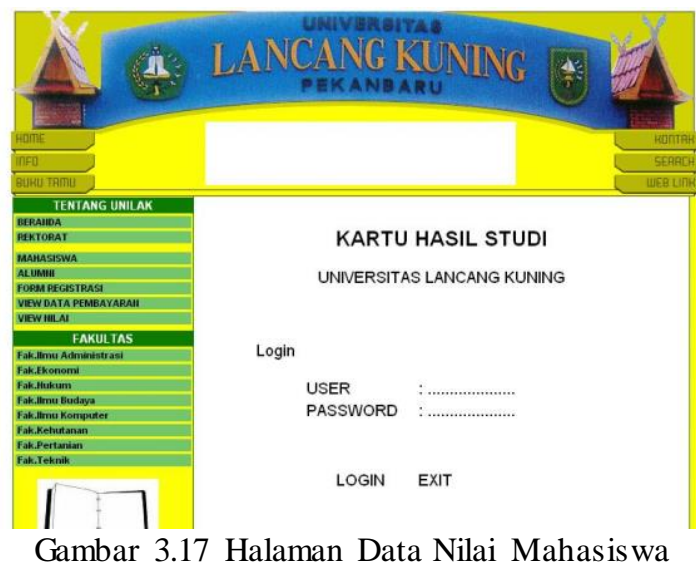

Halaman yang diperuntukkan bagi mahasiswa untuk dapat mengakses atau melihat nilai hasil studi. Sebelum masuk ke halaman ini mahasiswa juga harus memasukkan user id dan password.

\section{SIMPULAN}

Dari pembahasan penelitian Sistem Informasi Administrasi Akademis Berbasis Web yang telah dijelaskan pada bab-bab sebelumnya, 
maka dapat disimpulkan hal-hal sebagai berikut:

1. Dari penelitian yang telah dilakukan diperoleh Sistem Informasi Akademik di Universitas Lancang Kuning Pekanbaru yang mempermudah Bagian Biro Akademik dan stafnya dalam melaksanakan pekerjaan sehari-hari sehingga dapat memberikan pelayanan dan informasi yang berhubungan dengan akademik dengan cepat dan akurat.

2. Dengan memanfaatkan teknologi wbb proses perancangan dan pembuatan aplikasi menjadi lebih mudah dimana penggunanya hanya memerlukan browser internet, tanpa harus tergantung pada sistem operasi tertentu.

3. Penggunaan SQL server pada perancangan Sistem Informasi Akademik terlihat lebih efektif dan efisien.

4. Untuk penerapan peralatan teknologi sangat perlu mempertimbangkan jumlah karyawan, mahasiswa dan dosen yang sudah memanfaatkan teknologi Sistem Informasi Administrasi yang dibangun. Hal ini perlu dilakukan guna efisiensi dan efektifitas biaya dan peralatan yang tersedia.

\section{UCAPAN TERIMAKASIH}

Terimakasih diucapkan kepada Universitas Lancang Kuning yang telah mendukung secara moral atau materil demi terselesaikannya penelitian ini

\section{DAFTAR PUSTAKA}

Sidik, Betha, Ir. MySQL.Informatika. Bandung 2005.

I Made Gunadi, Lirva32. Joomla! Website Magic Dengan Joomla! Bikin Website semudah memasak mie Instan.Jasakom. Jakarta. 2007.

Firdaus. 7 Jam Belajar Interaktif PHP \& $M y S Q L$ dengan Dreamweaver.Maxikom. Palembang. 2007.
Purwanto, MT.Heru, S.Kom. Membangun Website Interaktif Sekolah. Andi Offset. Yogyakarta. 2007

Hidayatullah, A Taufik. Belajar Adobe Photoshop 7.0. Surabaya:Indah Surabaya. 2003.

H.A Moduto, Rahmat Hidayat, Yuhefizar. 2006 .Cara Mudah Membangun Website Interaktif menggunakan Content management Sistem. Jakarta:Gramedia

Yani, Ahmad. Panduan Membangun Jaringan Komputer. PT.Kawan Pustaka. Jakarta. 2007 